\title{
Recent fluctuations of glaciers in the Gongga mountains
}

\author{
Su Zhen, Liu Shiyin, Wang Ninglian and Shi Aiping \\ Lanzhou Institute of Glaciology and Geocryology, Chinese Academy of Sciences, Lanzhou 730000, China
}

\begin{abstract}
From field observations and historical information, it is found that there are generally three end moraines in front of glaciers in the Gongga mountains. These moraines were formed during the Little Ice Age and represent three glacier advances. During the last 100 years, the glaciers have been in continuous retreat except for two periods of stability or even slight advance, one in the beginning of the 20 th century, up to the 1920 s, and the other from the middle 1960 s to the early 1980 s. The amplitudes of glacier fluctuations were greater on the east slope than on the west.
\end{abstract}

\section{INTRODUCTION}

Lying between the Sichuan basin and the southeastern periphery of the Tibetan Plateau, the Gongga mountains, in which the highest peak is $7514 \mathrm{~m}$ a.s.l., are located in the middle of the Da Xueshan mountains. The Gongga mountains are $80 \mathrm{~km}$ long and 15 to $40 \mathrm{~km}$ wide, extending in a north-south direction. They are one of

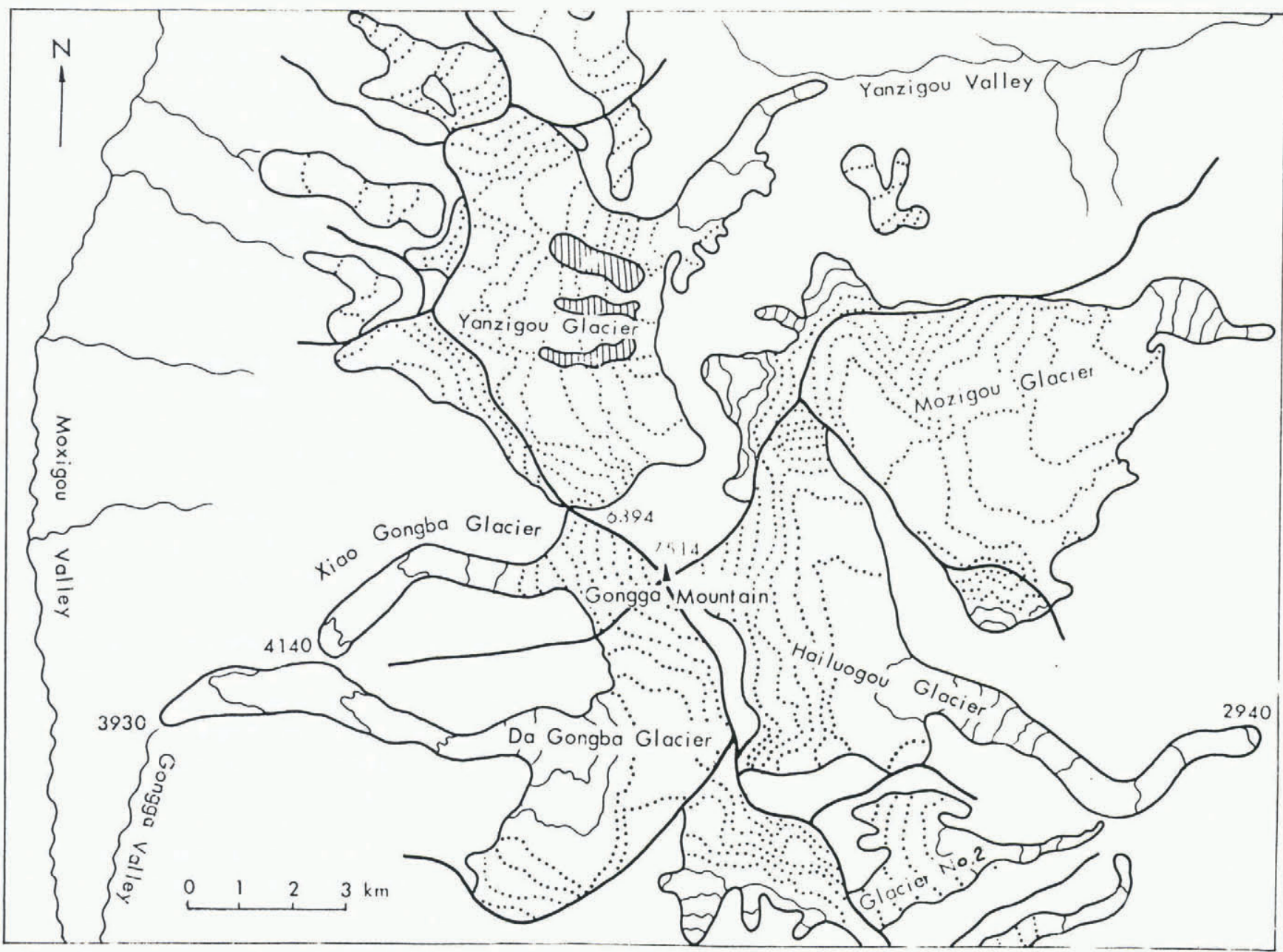

Fig. 1. Map of principal glaciers in the Gongga mountains. 


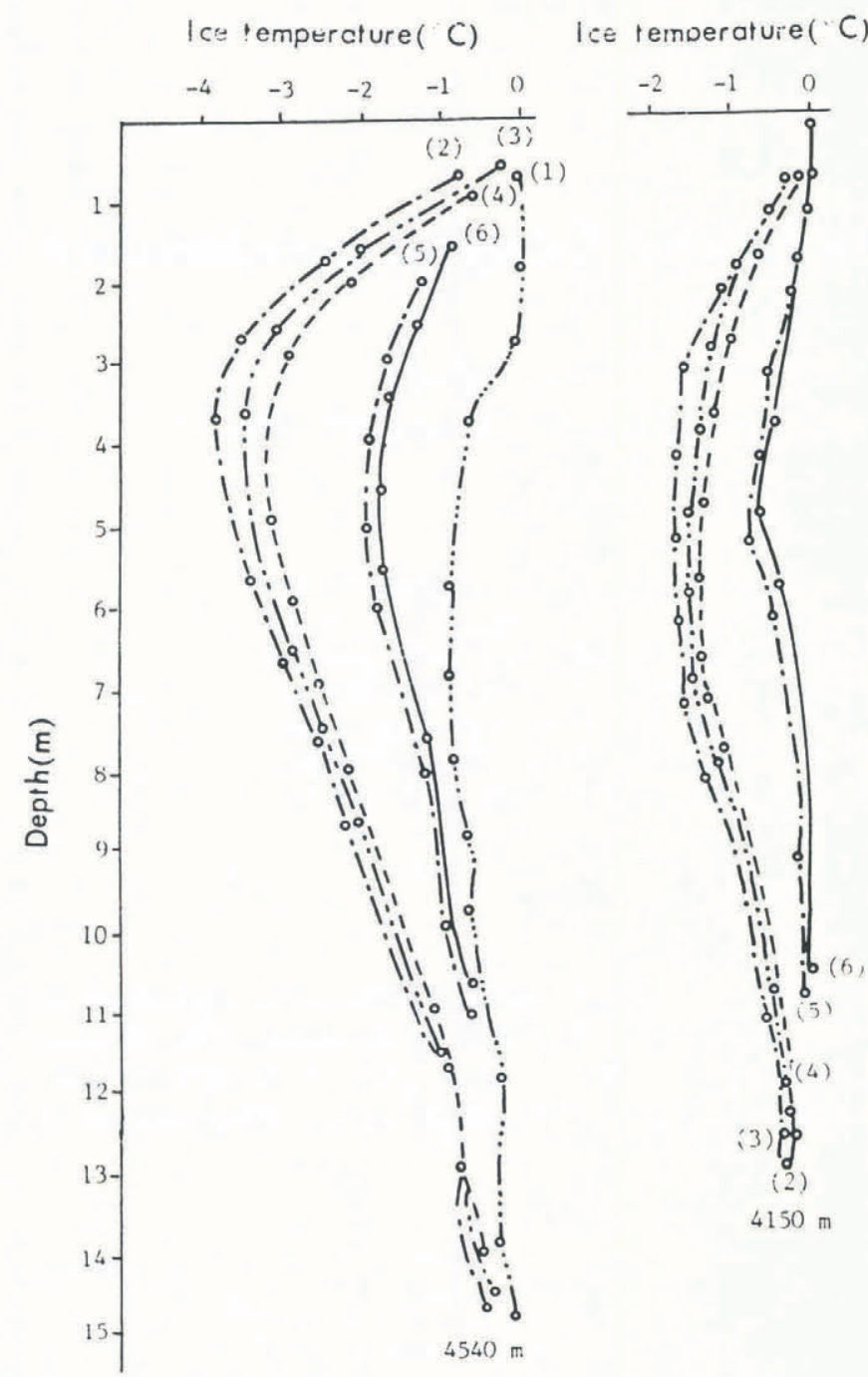

Fig. 2. Near-surface temperature profiles in the ablation area of $\mathrm{Da}$ Gongba Glacier. (1) 30 September 1982; (2) 16-18 May 1983; (3) 2526 May 1983; (4) $4-6$ June 1983; (5) 26 July 1983; (6) 6 August 1983.

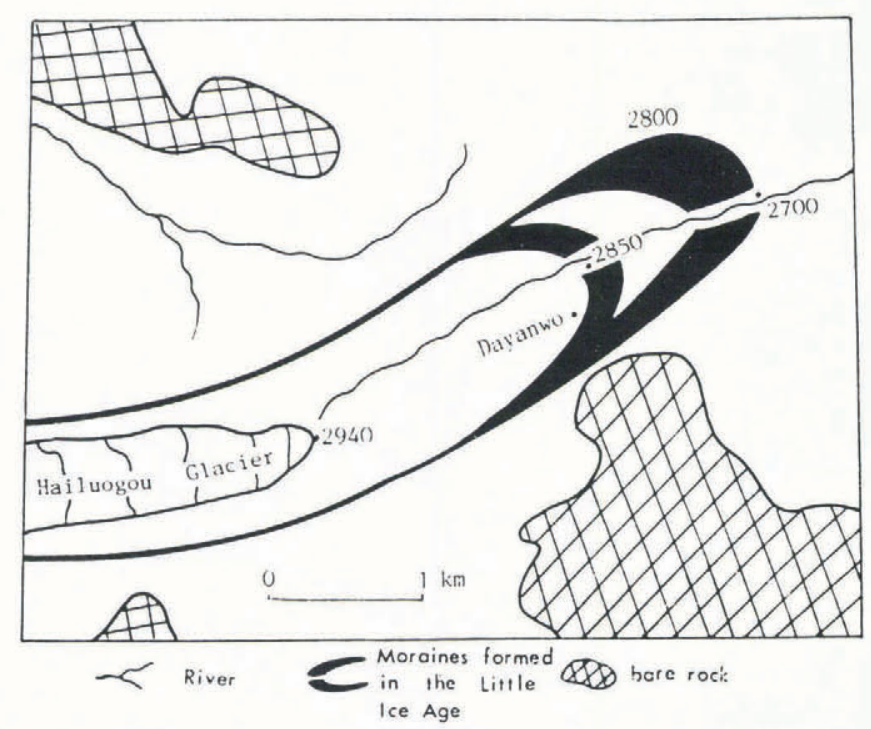

Fig. 3. Distribution of Little Ice Age moraines in front of Hailuogou Glacier. the principal glaciated areas controlled by the monsoon climate. Many scientists from China and other countries have undertaken glaciological investigations in this region (Heim, 1936; Anderson, 1939; Li, 1958; Cui, 1958). In this paper we study glacier fluctuations in the Gongga mountains during the Little Ice Age by comparing topographical maps and aerial and satellite photographs obtained at different times. New data presented here are mainly from field investigations, including repeated surveys during the period of the comprehensive expedition to the Tibetan Plateau of the Chinese Academy of Sciences (1981-83) and of the Sino-Soviet joint glaciological expedition to the Gongga mountains in 1990.

\section{GLACIER DISTRIBUTION AND CHARACTERIS- TICS}

There are 74 glaciers with a total area of $255.1 \mathrm{~km}^{2}$ and a volume of $24.6 \mathrm{~km}^{3}$ on the east and west slopes of the Gongga mountains. On the east slope there are 33 glaciers with an area of $154.6 \mathrm{~km}^{2}$ and a volume of $16.7 \mathrm{~km}^{3}$. The snow-line on these glaciers ranges from 4800 to $5000 \mathrm{~m}$ a.s.1. On the west slope there are 41 glaciers, with an area of $100.4 \mathrm{~km}^{2}$ and a volume of $7.8 \mathrm{~km}^{3}$; here the snow-line ranges from 5000 to $5200 \mathrm{~m}$ a.s.l. The number of glaciers is less on the east side than on the west, but the glacier area and volume on the east slope are larger, and snowline elevations are lower.

Among the four glaciers which are longer than $10 \mathrm{~km}$ in the Gongga mountains, three are located on the east slope, of which the longest, Hailuogou Glacier, is $13.1 \mathrm{~km}$ long and $25.7 \mathrm{~km}^{2}$ in area, and its terminus stretches to $2940 \mathrm{~m}$ a.s.l. (Fig. 1). The other two, Mozigou Glacier and Yanzigou Glacier, are 11.6 and $10.5 \mathrm{~km}$ long, respectively, with areas of 26.8 and $32.0 \mathrm{~km}^{2}$, and their termini reach to 3600 and $3680 \mathrm{~m}$ a.s.l., respectively. On the west slope, Da Gongba Glacier is $11 \mathrm{~km}$ long and $20.2 \mathrm{~km}^{2}$ in area and its terminus descends to $3930 \mathrm{~m}$ a.s.l.

The Gongga mountains have a vertical zonality. On their eastern slope, the basal zone is subtropical, with evergreen broadleaved forest. The precipitation in this region is mainly governed by the southeast and southwest monsoons, which bring more precipitation to the east slope than to the west. On the east slope the annual precipitation is $1871.6 \mathrm{~mm}$ and mean annual air temperature is $3.7^{\circ} \mathrm{C}$ at an altitude of $3000 \mathrm{~m}$ in the Hailuogou valley. It is estimated that the precipitation in the glacier accumulation area is around $3000 \mathrm{~mm}$. In contrast, at Gongga Temple ( $3700 \mathrm{~m}$ a.s.l.) on the west, the annual precipitation is $1173.6 \mathrm{~mm}$, the mean annual temperature is $1.9^{\circ} \mathrm{C}$ and the estimated precipitation is about $1800 \mathrm{~mm}$ in the glacier accumulation area. Consequently, altitudes of glacier termini and snow-lines are higher on the western than on the eastern slope.

Ice temperature is one of the major indicators of a glacier's character. Observations revealed that temperatures of glaciers in the Gongga mountains are relatively high. The near-surface temperature in the ablation area of Hailuogou Glacier was at the melting point in October-November 1990, and ice formation was controlled mainly by the warm infiltration. The massbalance gradient is higher than that in northwest 
China. The flow velocity is about $180 \mathrm{~m} \mathrm{a}^{-1}$ in the middle and upper sections of the ablation area. Thus it appears that glaciers on the east slope may be maritime (temperate). However, near-surface temperatures in the upper part of the ablation area of Da Gongba Glacier on the west remain subfreezing in summer (Fig. 2).

\section{GLACIER FLUCTUATIONS IDENTIFIED FROM THE END AND LATERAL MORAINES}

In front of glaciers in the Gongga mountains there are generally newly formed end and lateral moraines, of which three typical ones lie between a few hundred metres and $3 \mathrm{~km}$ from the glacier termini. These fresh moraines record the advances and retreats of the glaciers. For example, three distinct moraines lie around the tongue of the Hailuogou Glacier (Fig. 3). The innermost moraine, with an arc-shape across the valley, lies at $2850 \mathrm{~m}$ a.s.l., $1.65 \mathrm{~km}$ from the tongue. Its two sides, about $30 \mathrm{~m}$ high, connect with lateral moraines. Its central section, with only 5 to $10 \mathrm{~m}$ of relief and covered with Hippophae vegetation, has been eroded by water. The older lateral moraine is found on both sides of the valley and is fully vegetated with Picea species. The outermost end moraine ( $2800 \mathrm{~m}$ a.s.l.) is 50 to $100 \mathrm{~m}$ above the valley floor $(2700 \mathrm{~m}$ a.s.l.). It is also arc-shaped and covered with Hippophae vegetation. The intermediate moraine overlaps the outer one, so they are difficult to distinguish from each other topographically.

These moraines are composed mainly of debris from granite, quartz sandstone and so forth, and are covered with shrubbery. They are fresh and composed of loose material with big boulders, some of which are up to $5 \mathrm{~m}$ in diameter.

The lower limit of buried ice under the thick moraine in front of the Da Gongba Glacier (Fig. 4) on the west

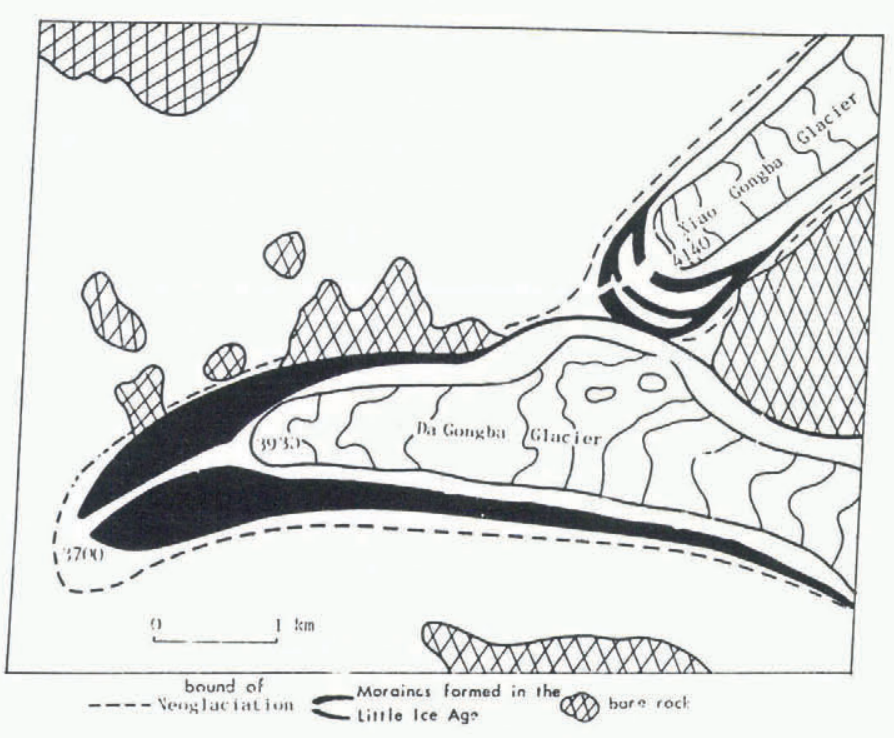

Fig. 4. Distribution of Little Ice Age moraines in front of Da Gongba Glacier and Xiao Gongba Glacier. slope may be as low as $3850 \mathrm{~m}$ a.s.l. although its tongue is at an elevation of $3930 \mathrm{~m}$ a.s.l., and fresh moraine ends at about $3700 \mathrm{~m}$ a.s.l. The fresh and the older moraines overlap, forming a great cone, $240 \mathrm{~m}$ above the valley floor. Curiously, there was no distinct boundary between the present terminus and the fresh moraines around $\mathrm{Da}$ Gongba Glacier. A few fresh moraines can be recognized some distance from the terminus. They are characterized by fresh till overlapping the older moraines, and by an opening formed in the end moraine. The glacier once flowed through this opening, leaving fresh moraine there. The fresh moraine is mainly composed of granitic debris. In the area of the confluence between Da Gongba Glacier and Xiao Gongba Glacier, three fresh moraines are recognized. Of them, the outermost is composed of granite, sandstone and shale debris. In front of these three moraines there is an older one beside $\mathrm{Da}$ Gongba Glacier which was left during a period when the two glaciers were joined together. Now vegetation, including shrubbery, is growing on it. Other moraines in this area, 300 to $350 \mathrm{~m}$ from the tongue of Xiao Gongba Glacier, are composed mainly of sandstone and shale debris which seems to have been left during the retreat of Xioa Gongba Glacier when it separated from Da Gongba Glacier. These moraines are fresh and loose. Some herbage is sparsely scattered on them

${ }^{14} \mathrm{C}$-dating of decayed wood buried in the outermost moraines indicates that the fresh moraines of Hailuogou Glacier ( $2730 \mathrm{~m}$ a.s.l.) were formed since $608 \pm 79$ a BP and the end moraines of $\mathrm{Da}$ Gongba Glacier and Xiao Gongba Glacier were formed since $620 \pm 40$ and $440 \pm 50$ a BP, respectively (personal communication from Feng Zhaodong and others). Based on this and other relevant studies (Heim, 1936), the three fresh end moraines surrounding the glaciers in the Gongga mountains appear to have been formed in the period of the 15th to 19th centuries, corresponding to the Little Ice Age. Moraines reflecting three glacier advances are present.

During the Little Ice Age, glaciers expanded at different rates in different places around the Gongga mountains. In general, on the east slope, large glaciers expanded 2 to $3 \mathrm{~km}$, intermediate ones 1 to $2 \mathrm{~km}$ and small ones about $1 \mathrm{~km}$. However, on the west slope they expanded only 0.2 to $1.5 \mathrm{~km}$.

\section{FLUCTUATIONS OF THE MODERN GLACIERS}

In this section we discuss fluctuations of glaciers since the beginning of this century when new instruments for direct monitoring of environmental variations came into use. The Little Ice Age probably terminated early in this period. Successive expeditions, comparison of topographic maps, aerial photographs and written records from different times, and interviews with local residents have revealed that glaciers were generally retreating, but this retreat was interrupted by two periods of stability or slight advance.

Glaciers in the Gongga mountains were in retreat from the late 19th to the early 20th centuries but they appeared to be stationary, or even to advance, from the early 20 th century to the 1920 s. In the summer of 1930 , 
Heim (1936) found that the terminus of Hailuogou Glacier was $20 \mathrm{~m}$ from the upper side of a fresh end moraine (quoted from Huang, 1941). He noted that glaciers had been in retreat sine the late 19 th century, and yet had become merely $20 \mathrm{~m}$ shorter in several decades. By measuring the distance between the glacier tongue and the nearest fresh moraine on the (1:200000 scale) topographic map surveyed by E. Imhof in 1930 (Heim, 1936), it was also found that a great number of glaciers in the Gongga mountains had been stationary or had advanced from the early 20 th century to the 1920 s.

Glaciers were in intensive retreat from 1930 to 1966.
For example, the terminus of Hailuogou Glacier retreated $1150 \mathrm{~m}$ from the position Heim (1936) described in 1930 to that identified by aerial photographs taken in December 1966, an annual rate of $32 \mathrm{ma}^{-1}$. A small glacier called Glacier No. 2 was a tributary to Hailuogou Glacier in 1930, but they were separated from each other by $800 \mathrm{~m}$ in December 1966, a retreat rate of $22.2 \mathrm{~m} \mathrm{a}^{-1}$. Other glaciers behaved similarly. According to Heim's description, a small glacier from the northwest flowed into Yanzigou Glacier at a position 3 to $4 \mathrm{~km}$ above its terminus, but in December 1966 this distance was only $650 \mathrm{~m}$. The total retreat was thus at least $2350 \mathrm{~m}$ during

Table 1. Changes in the termini of glaciers in the Gongga mountains

\begin{tabular}{|c|c|c|c|c|c|}
\hline Position & Glacier & Duration & $\begin{array}{c}\text { Terminus } \\
\text { Advance }(+) \text { or retreat (-) } \\
\mathrm{m}\end{array}$ & $\begin{array}{l}\text { Advance or } \\
\text { retreat rate } \\
\qquad \mathrm{m} \mathrm{a}^{-1}\end{array}$ & Source \\
\hline
\end{tabular}

Hailuogou

From the beginning of the 20 th century

to 1930

1930-Dec. 1966

Dec. 1966-Jan. 1981

Jan. 1981-Dec. 1989

Jan.-Oct. 1990

No. 2 in

East Hailuogou

slope valley

From the beginning

of the 20th century

to 1930

1930-Dec. 1966

Dec. 1966-Jan. 1981

Jan. 1981-Nov. 1990

Yanzigou

From the beginning of the 20th century

to 1930

1930-Dec. 1966

Dec. 1966-Dec. 1981

Dec. 1981-1983

1983-1990 stationary or advance

$\begin{array}{ll}-1150 & -32 \\ -177.8 & -12.7 \\ -170 & -19.0 \\ -22.65 & -27.1\end{array}$

connected with the

Hailuogou Glacier

$\begin{array}{cc}-800 & -22.2 \\ \text { stationary } & \sim 0 \\ -250 \text { to }-300 & -25 \text { to }-30\end{array}$

stationary or advance

$\begin{array}{cc}-2350 & -65.3 \\ -300 & -20 \\ \text { stationary } & \sim 0 \\ -200 & -28.6\end{array}$

Heim, 1936

aerial photo and map aerial photo and investigated aerial photo and measured measured

Heim, 1936

aerial photo and map aerial photo and measured measured

Heim, 1936

aerial photo and map aerial photo and measured measured measured
Da Gongba From the beginning of the 20th century to 1930 1930-Dec. 1966 Dec. 1966-1981

West 1981-1990

slope
Xiao Gongba From the beginning of the 20 th century to 1930 1930-Dec. 1966 Dec. 1966-1981 1981-1990

stationary

$$
\begin{gathered}
-175 \\
\text { stationary } \\
-25
\end{gathered}
$$

stationary

$$
\begin{aligned}
& -85 \text { to }-200 \\
& \text { stationary } \\
& -10 \text { to }-15
\end{aligned}
$$
-2.4 to -5.6 $\sim 0$$$
-1 \text { to }-1.5
$$
$\sim 0$

Heim, 1936

$-4.9 \quad$ aerial photo and map $\sim 0 \quad$ aerial photo and measured -2.5 measured

$\sim 0 \quad$ Heim, 1936

aerial photo and map aerial photo and measured measured 
36 years, or $65.3 \mathrm{~m} \mathrm{a}^{-1}$. Despite the fact that the glaciers on the west slope in this region were relatively more stable, retreat also occurred from 1930 to 1966. For instance, the terminus of $\mathrm{Da}$ Gongba Glacier retreated $175 \mathrm{~m}$ within this period, a retreat rate of $4.9 \mathrm{~m} \mathrm{a}^{-1}$, and Xiao Gongba Glacier retreated 85 to $200 \mathrm{~m}$, a rate of 2.4 to $5.6 \mathrm{~m} \mathrm{a}^{-1}$ (Table 1).

Comparisons of photographs taken in 1966 and 1981 reveal that the rate of retreat of most glaciers in the Gongga mountains decreased, and some became stationary or advanced. On Hailuogou Glacier, for example, the retreat rate decreased from 32 to $12.7 \mathrm{~m} \mathrm{a}^{-1}$, while Glacier No. 2 in the Hailuogou valley became stationary in the same period. Yanzigou Glacier became stationary in 1981. Da Gongba and Xiao Gongba glaciers were also stationary from 1966 to 1981 (Table 1).

From the beginning of the 1980s to the present, most glaciers in the Gongga mountains began to retreat again, and the retreat rate increases annually. For example, the mean annual retreat rate of Hailuogou Glacier changed from 12.7 to $19 \mathrm{~m} \mathrm{a}^{-1}$ and then its terminus retreated another $22.65 \mathrm{~m}$ from January to October 1990. Glacier No. 2 had a mean annual retreat rate of 25 to $30 \mathrm{~m} \mathrm{a}^{-1}$, but Da Gongba and Xiao Gongba glaciers had relatively small retreats.

\section{CONCLUSION}

Most of the glaciers in the Gongga mountains are of intermediate to small size. They should respond sensitively to short-period and small-amplitude climatic changes. The glacier fluctuations documented herein are: (1) Glaciers in the Gongga mountains advanced during the Little Ice Age, as they did elsewhere in China and around the world, and three fresh end and lateral moraines were formed. The most intensive advance occurred in the 17th century. Retreat has been the rule since the 19th century, interspersed, however, with two periods of stability or advance, one from the early part of the century to the 1920 s and one from the middle 1960 s to the beginning of the 1980s. (2) Glaciers are becoming smaller. For instance, the area of Da Gongba Glacier was $26.3 \mathrm{~km}^{2}$ in the 15 th century, and $22.8 \mathrm{~km}^{2}$ in the 19 th century and is now $20.22 \mathrm{~km}^{2}$. (3) Altitudes of snow-lines and of glacier termini are increasing. Taking Da Gongba Glacier as an example, the elevations of the snow-line and glacier terminus were 4950 and $3700 \mathrm{~m}$ in the 15 th century and 4990 and $3900 \mathrm{~m}$ in the 19th century. Now they are 5010 and $3930 \mathrm{~m}$, respectively. (4) Glaciers on the east slope of the Gongga mountains have varied more significantly than those on the west slope. Thus glaciers on the east slope are more active, confirming the idea that the response to climatic change of glaciers located on the southeastern periphery of the Tibetan Plateau is more vigorous than that of glaciers on the central plateau.

\section{REFERENCES}

Andersson, J. G. 1939. Topographical and archaeological studies in the Far East. Östasiatiska Samlingarna. Bulletin (Stockholm), 11, 110.

Cui Zhijiu. 1958. Preliminary observations of glaciers in the Gongga mountains. Acta Geographica Sinica, 24(3), 318-338. [In Chinese.]

Heim, A. 1936. The glaciation and solifluction of Minya Gongkar. Geogr. 7., 87(5), 444-454.

Huang Jiqing. 1941. Glaciers in China. F. Glaciol. Cryopedol., 6(1), 85-93. [In Chinese.] [Originally published in Fournal of Literature and History, 1(8), 1941, 31-41.]

Li Chengshan. 1958. Gongga mountains. Geographical Knowledge, 2, 65-67. [In Chinese.]

The accuracy of references in the text and in this list is the responsibility of the author/s, to whom queries should be addressed. 